\title{
Exploring Credibility of Indonesian Islamic Bank: An Exploratory Factor Analysis (EFA) Approach
}

\author{
Naufal Bachri ${ }^{1}$, M. Shabri Abd Majid ${ }^{2}$ and Wahyuddin Albra ${ }^{3}$ \\ \{naufal.bachri@unimal.ac.id¹, mshabri@unsyiah.ac.id²,wahyuddin@unimal.ac.id ${ }^{3}$ \} \\ ${ }^{1}$ Department of Management Science, Universitas Malikussaleh, Indonesia \\ ${ }^{2}$ Department of Islamic Economics, Syiah Kuala University, Indonesia \\ ${ }^{3}$ Department of Accounting, Universitas Malikussaleh, Indonesia
}

\begin{abstract}
This study attempts to explore the antecedents of credibility of full-fledged Islamic banks in Indonesia. The respondents who have a bank account in full-fledged Islamic bank for at least one year. The data were collected from respondent using the structured questionnaires. A total of 250 questionnaires were distributed to the customers of major Islamic banks that in the Aceh Province, Indonesia. The study documented that credibility refers to a multidimensional construct composed of three factors: reliability, concern and knowledge. A scale of overall credibility in Islamic Bank was obtained, comprising three dimensions with 21 indicators that were significant for their measurements. The factor of concern refers to the key of establishing and maintaining long-term relationships between companies and customers. In addition, knowledge can increase responsiveness to customers, improve work efficiency and ability to innovate. However concern and knowledge are the new factors in the theory of credibility that can be applied in the Islamic Banks.
\end{abstract}

Keywords: $\quad$ Credibility, Reliability, Concern, Knowledge, Islamic Banks

\section{Introduction}

Credibility is the main element of company reputation. It refers to the level of customer trust in the company in creating and delivering products and services. Companies must have high credibility to influence consumer perception and attitude toward the company. Therefore, creating and maintaining the company credibility can improve financial performance, sales, long-term business relationships, and the company's success widely.

The concept of the Islamic Banks is the financial concept fully embraces the law of Sharia. The Law of Islamic Bank governs a business based on the partnership program, sharing risks and profits without interests (Usury). The system has rapidly become a worldwide concern. As evidence, there were 180 Islamic banks with branches more than 8,000 units in Asia, Africa, Europe and America (Rizwan et al., 2014).

Indonesia has 88.1 percent Muslim population, who conducts transaction with both conventional and Islamic banks. In 2015, it has 12 units of full-fledged Islamic banks, 22 units of dual window Islamic banks and 161 units of Islamic rural banks. The financial performance of Islamic bank experienced decreasing. Capital Adequate Ratio (CAR) was 14.09 percent compared to 15.74 percent in 2014. Return On Asset (ROA) was 0.89 percent compared to 0.79 percent in 2014 and Return On Equity (ROE) is 7.97 percent compared with 5.85 percent (Otoritas Jasa Keuangan, 2015). Additionally, Otoritas Jasa Keuangan (2015) reported that market share of Islamic bank achieved 4.78 percent to the entire market share of the national banking industry in Indonesia. It was still stand at the minimal target of 
5 percent. Koesen (2012) added that there was negative opinion of Indonesian toward Islamic bank, namely; (1) system of Islamic and conventional bank is the same, (2) for dual window system, capital source of Islamic bank is from conventional bank, (3) costs of Islamic bank is more expensive than conventional bank, (4) the achieved profit is uncertain. (5) the perceived service by customers are still stiff, less friendly, less sophisticated technology, less knowledgeable about Islamic products and complicated procedure. This indicates that the Indonesian is less trusting of Islamic banks.

Against these backdrops, this study attempts to identify the antecedents of credibility of the Islamic bank in Indonesia by adapting and modifying the corporate credibility model (Haley, 1996; Eisend, 2006). Specifically, it attempts to find the special dimensions of corporate credibility in the Islamic banking sector. These dimensions are useful for the Islamic Banks in creating and maintaining consumer loyalty and enhancing their corporate performances.

\section{Literature Review}

\subsection{Definition of Credibility}

Keller \& Aaker (1998) state that credibility is the consumer to believe that the company can design and deliver products and services that satisfies the needs and desires of consumers. Newell \& Goldsmith (2001) defines the company's credibility refers the feel of consumers that companies have the knowledge or ability to meet claims. Maathuis et al., (2004) says that credibility is a fundamental asset for a person, organization, political party, or media products to achieve their goals.

Company credibility is as a variable of the predictor in marketing (Ballentine, 2006; Goldsmith et al., 2000) and a key to maintaining the long-term relationship in the business environment (Ghorban \& Tahernejad, 2012). Thus, credibility reflects a company's reputation (Kotler \& Keller, 2013), is the sub-processes of a company's reputation (Adams \& Mehran, 2011). Goldsmith et al., (2000) say that credibility as a predictor of consumer desire to buy.

\subsection{Effects of Credibility}

There have been several studies explained the internal and external impacts of credibility. Internally, credibility can increase the growth and profit for the company, while externally, credibility impacts on consumer value, satisfaction, commitment and loyalty (TABLE I).

Table 1. Effects Of Credibility

\begin{tabular}{lll}
\hline No & Sources & The effects \\
\hline 1 & Fombrun(1996) & $\begin{array}{l}\text { Credibility is company reputation that influence the company } \\
\text { succes }\end{array}$ \\
\hline 2 & Keller \&Aaker(1998) & $\begin{array}{l}\text { Credibility is the level of consumers trust for the company in } \\
\text { designing and delivering products and services }\end{array}$ \\
\hline 3 & $\begin{array}{l}\text { Newell \& } \\
\text { Goldsmith(2001) }\end{array}$ & Credibility can positevely influence on company performance \\
\hline 4 & Goldsmith et al.(2000) & $\begin{array}{l}\text { The company credibility positevely correlates with customer } \\
\text { satisfaction }\end{array}$ \\
\hline 5 & Erdem et al.(2002) & $\begin{array}{l}\text { The credibility of the company is consumer trust in all } \\
\text { products and services produced, definetely, can satisfy the }\end{array}$ \\
\hline
\end{tabular}




\begin{tabular}{lll}
\hline & & desires of consumers. \\
\hline 6 & Ghorban(2012) & $\begin{array}{l}\text { Credibility has positevely correlation with commitment and } \\
\text { sustained commitment loyal customers }\end{array}$ \\
\hline 7 & Careras et al.(2013) & $\begin{array}{l}\text { Credibility can influence behavior and increase the value for } \\
\text { stakeholders }\end{array}$ \\
\hline 8 & Sallam(2014) & $\begin{array}{l}\text { The credibility of the company can improve the satisfaction } \\
\text { and word of mouth communication }\end{array}$ \\
\hline 9 & Bachri et al.(2016) & $\begin{array}{l}\text { The credibility will be the trend for future study in islamic } \\
\text { Bank }\end{array}$ \\
\hline
\end{tabular}

As observed from Table 1, there are direct and indirect relationships between the credibility, consumer value, satisfaction, commitment, loyalty and performance of company. Variable of credibility is also an important element in creating customer value, satisfaction and loyalty and also increasing performance.

\subsection{Antecedents of Credibility}

Variable of credibility does not come about easily, but it is formed from several subvariables. Table II lists the determinants of credibility, for a more details as follows:

Table 2. Antecedents Of Credibility

\begin{tabular}{cll}
\hline No & \multicolumn{1}{c}{ Sources } & \multicolumn{1}{c}{ Antecedents } \\
\hline 1 & $\begin{array}{l}\text { Newell \& Goldsmith (2001); Sweeney \& Swait } \\
(2008)\end{array}$ & Expertise \& trustworthiness \\
\hline 2 & Van Riel (1995); Keller \& Aaker (1998) & Reliability, expertise \& attractive \\
\hline 3 & Haley (1996) & $\begin{array}{l}\text { Trustworthiness, expertise, attractive \& } \\
\text { relevance }\end{array}$ \\
\hline 4 & Goldsmith et al. (2000) & $\begin{array}{l}\text { Expertise, attractiveness, power \& } \\
\text { trustworthiness }\end{array}$ \\
\hline 5 & Eisend (2006) & Trustworthiness, competence \& dynamism \\
\hline 6 & Kotler \& Keller (2013) & Trustworthiness, expertise, \& likability \\
\hline
\end{tabular}

There are several types of antecedents to form variables of credibility, namely: reliability, expertise, attractiveness, power, trust, likability, and relevance. Additionally, the credibility has two main dimensions, namely expertise and trustworthiness.

\section{Methodology}

The aim of this study is to identify how customers of the full-fledged Islamic banks in Indonesia measure their credibility. In selecting the respondents, the purposive random sampling technique with criteria; each respondent has a bank account in full-fledged Islamic bank for at least one year, was taken. The data were collected from the respondents using the structured questionnaires. A total of 250 questionnaires were distributed to the c u st o mer of six major Islamic banks (i.e., PT. Bank Muamalat Indonesia, PT. Bank BRIsyariah, PT. Bank BNI Syariah, PT. Bank Syariah Mandiri, PT. Bank Mega Syariah, PT. Bank Maybank Syariah Indonesia, PT. Bank Tabungan Pensiunan Nasional Syariah) that are operating in the Aceh Province, Indonesia. 
A five-point Likert scale was used to measure perception of Islamic bank credibility, ranging from "strongly disagree" (1) to "strongly agree" (5). Credibility was measured by adapting indicators as suggested by Haley (1996) and Eisend (2006). To explore credibility of Islamic bank, the Exploratory Factor Analysis (EFA) approach is used in the study.

\section{Findings And Discussion}

\subsection{Respondent Profile}

Table 3 reports the descriptive statistics of the respondents in this study. A total of 250 questionnaires were distributed and 173 were returned ( 70.4 percent response rate). The sample characteristic includes 94 male customers (54.3 percent) and 79 female customers (45.7 percent). The dominant respondents' age is $30-41$ years (37.6 percent) and works as businessman (38.7 percent).

Table 3. Respondent Profile

\begin{tabular}{llll}
\hline & Frequency & Percent & Cumulative Percent \\
\hline Gender & & & \\
\hline Male & 94 & 54.3 & 54.3 \\
\hline Female & 79 & 45.7 & 100.0 \\
\hline Age(year) & & & \\
\hline $18-23$ & 12 & 6.9 & 6.9 \\
\hline $24-29$ & 44 & 25.4 & 32.4 \\
\hline $30-35$ & 65 & 37.6 & 69.9 \\
\hline $36-41$ & 41 & 23.7 & 93.6 \\
\hline 42 and above & 11 & 6.4 & 100.0 \\
\hline Occupation & & & \\
\hline Government employee & 38 & 22.0 & 22.0 \\
\hline Private employee & 24 & 13.9 & 35.8 \\
\hline Businessman & 67 & 38.7 & 74.6 \\
\hline Student & 25 & 14.5 & 89.0 \\
\hline Other & 19 & 11.0 & 100.0 \\
\hline Education & & & \\
\hline High school & 20 & 11.6 & 11.6 \\
\hline Undergraduate & 46 & 26.6 & 38.2 \\
\hline Graduate & 87 & 50.3 & 88.4 \\
\hline Postgraduate & 20 & 11.6 & 100.0 \\
\hline & & &
\end{tabular}

\subsection{Assumption Tests of Factor Analysis}

The Kaiser Meyer Olkin Measure of Sampling (KMO) test shows the value of 0.923. This value is higher than 0.6 (i.e., 0.6-0.99). The Barlett Test of Spehricity is 2482.188 and the probability associated with the chi-squared statistic is lower than 0.05 . The Measures of Sampling Adequacy (MSA) test has the Anti-Image Correlation values higher than 0.5 (i.e., 0.50-0.99). Subsequently these assumptions have met eligibility for factor analysis to be conducted for further analysis. 


\subsection{Communalities Analysis}

To validate the scale of credibility, the study carried out communalities analysis of 22 indicators. The study found that the values of extraction are higher than 0.5 (i.e., $0.50-0.99$ ) except indicator of reputation (X6). Furthermore indicator of reputation (X6) must be excluded the next analysis. Consequently, total of indicators used in the analysis is 21 indicators.

\subsection{Grouping the Antecedents of Credibility}

Eigenvalue Analysis showed that total factor of credibility is 3 factors. Total Eigenvalues obtained are higher than 1 (Acceptance > 1). Initial eigenvalue for component 1 is 10.830, for component 2 is 1.346 and component 3 is 1.045 . While component of $4-21$ have eigenvalues lower than 1 .

Rotation method or principal component analysis was performed to determine which indicators are parts of the credibility's factors (Factor 1, factor 2 and factor 3). Rotation Method using Varimax with Kaiser Normalization showed that factor 1 has ten indicators namely; reliability, recognition, justice, social responsibility, sincerity, ethic, ability, experience, positive opinion and like. Value of Cronbach's Alpha for factor 1 is 0.922 (i.e., $0.70-0.99)$. The factor is labelled the factor of reliability. Factor 2 has seven indicators namely; familiarity, delight, consistency, honesty, concern, understand and mutual sharing. Value of Cronbach's Alpha for factor 2 is 0.866 (i.e., 0.70-0.99). The factor is labelled the factor of concern. Finally factor 3 has four indicators namely; knowledge, expertise, qualify and prestigious. Value of Cronbach's Alpha for factor 3 is 0.866 (i.e., 0.70-0.99). The factor 3 is labelled the factor of knowledge.

Meanwhile, the component transformation is also conducted for validating three dimensions of credibility in the Islamic Bank

Table 4. Component Transformation Matrix

\begin{tabular}{llll}
\hline Components & $\mathbf{1}$ & $\mathbf{2}$ & $\mathbf{3}$ \\
\hline Reliability & .671 & .592 & .447 \\
\hline Concern & -.617 & .780 & -.106 \\
\hline Knowledge & -.411 & -.205 & -888 \\
\hline
\end{tabular}

Factor reliability has correlation of 0.671 (i.e., $0.50-0.99)$. Factor concern has correlation of 0.780 (i.e., 0.50-0.99). Finally Factor knowledge has correlation of 0.888 (i.e., 0.50-0.99). These mean that credibility of the Islamic Bank in Indonesia has three factors namely reliability, concern and knowledge.

\section{Conclusions}

The purpose of this study is to explore variable of credibility for the full-fledged Islamic bank. This study expands the existing literature by exploring credibility in the sector of Islamic bank. Previous researches have the different dimensions, namely expertise and trust (Belch \& Belch, 2012; Newell \& Goldsmith, 2001; Erdem et al. 2002; Sweeney \& Swait, 2008). Haley (1996) developed four dimensions, namely; expertise, attractive, trust and relevance. Goldsmith et al. (2000) added dimension of attractive and power so that it becomes four dimensions, namely: expertise, attractive, power and trustworthiness. In contrast to Kotler \& Keller (2013) added dimension likability to become three dimensions namely 
expertise, trustworthiness and likability. While Van Riel (1995); Koller \& Keller (2013) have the same pastures that dimension of credibility consists of three dimensions: reliability, expertise and attractive.

\section{Implications}

In Islamic banking industry in Indonesia have three dimensions of credibility that should be considered namely reliability, concern and knowledge. Reliability is documented as an important factor in measuring credibility because it can increase the quality of service and satisfaction to customers. This factor supports the opinion of the Van Riel (1995) and Keller \& Aaker (1998), who stated that reliability is an important element of the company's credibility. The factor of concern refers the key to establishing and maintaining long-term relationships between companies and customers. In addition, concern may increase the customer commitment and loyalty for the Islamic banks. The last factor is knowledge, can increase responsiveness to customers; improve work efficiency, and ability to innovate. However concern and knowledge are new factors in the theory of credibility that can be applied in Islamic Banking.

\section{Suggestions for the Future Studies}

Credibility is a major driver in creating and maintaining customer satisfaction and loyalty. Satisfaction and loyalty of consumers have implications on the success of companies such as growth and profitability in the long term. Concern and knowledge are new elements that must be considered in the Islamic banks because they have a significant impact on the progress of the banks. Therefore, future research should focus on factor of concern and knowledge to measure credibility of the Islamic banking industry.

\section{ACKNOWLEDGMENT}

The authors are very grateful to Professor Abdul Rahman Lubis and Professor Nasir Azis for consulting the data and paper

\section{REFERENCES}

[1] Adams, R. B., \& Mehran, H. (2011). Corporate Performance, Board Structure, and Their Determinants in the Banking Industry in the Banking Industry. Federal Reserve Bank of New York Staff Reports, no. 330. https://doi.org/10.2139/ssrn.302593

[2] Ballentine, A. J. (2006). Measuring Organizational Sponsorship Credibility: The Application of Source Credibility Theory in Determining The Most Effective Advocacy Advertisement Sponsor. University of Florida.

[3] Belch, G. E., \& Belch, M. A. (2012). Advertising and Promotion. An Integrated Marketing Communication perspective. Irwin: Homewood, IL.

[4] Eisend, M. (2006). Source Credibility Dimensions in Marketing Communication - A Generalized Solution. Journal of Empirical Generalisations in Marketing, 1-33.

[5] Erdem, T., Swait, J., \& Louviere, J. (2002). The impact of brand credibility on consumer price sensitivity. International Journal of Research in Marketing, 19(1), 119. https://doi.org/10.1016/S0167-8116(01)00048-9 
[6] Ghorban, Z. S., \& Tahernejad, H. (2012). A Study on Effect of Brand Credibility on Word of Mouth: With Reference to Internet Service Providers in Malaysia. International Journal of Marketing Studies, 4(1), 26-38. https://doi.org/10.5539/ijms.v4n1p26

[7] Goldsmith, R. E., Lafferty, B. A., \& Newell, S. J. (2000). The Impact of Corporate Credibility and Celebrity Credibility on Consumer Reaction to Advertisements and Brands. Corporate Reputation Review, 3(3), 304-318. https://doi.org/10.1057/palgrave.crr.1540122

[8] Haley, E. (1996). Exploring the construct of organization as source: Consumers' understandings of organizational sponsorship of advocacy advertising. Journal of Advertising, 25(2), 19-35. https://doi.org/10.1080/00913367.1996.10673497

[9] Keller, K. L., \& Aaker, D. A. (1998). The Impact of Corporate Marketing on a Company's Brand Extensions. Corporate Reputation Review, 1(4), 356-378. https://doi.org/10.1057/palgrave.crr.1540057

[10] Koesen, D. (2012). Selamat Tinggal Bank Konvensional: Haramnya Bank Konvensional dan Utamanya Bank Syariah. Jakarta: Penerbit Tifa Publishing House.

[11] Maathuis, O., Rodenburg, J., \& Sikkel, D. (2004). Credibility, Emotion or Reason? Corporate Reputation Review, 6(4), 333-345.

[12] Newell, S., \& Goldsmith, R. (2001). The development of a scale to measure perceived corporate credibility. Journal of Business Research, 52(1), 235-247. https://doi.org/10.1016/0005-7967(65)90040-9

[13] Otoritas Jasa Keuangan. (2015). Islamic Banking Statistics. Annual Report, 1-65.

[14] Rizwan, M., Yaseen, G., Nawaz, A., \& Hussain, L. (2014). Incorporating Attitude towards Islamic Banking in an integrated Service Quality, Satisfaction, Trust and Loyalty Model. International Journal of Accounting and Financial Reporting, 4(2), $456-477$.

[15] Sweeney, J., \& Swait, J. (2008). The Effect of Brand Credibility on Customer Loyalty. Journal of Retailing and Consumer Service, 15, 179-193. https://doi.org/10.1016/S0210-0266(08)70023-2

[16] Van Riel, C. B. M. (1995). Principles of Corporate Communication. New Jersey: Prentice Hall Englewood Cliffs. 